INTERNATIONAL JOURNAL OF

ECO-CULTURAL TOURISM, HOSPITALITY PLANNING

AND DEVELOPMENT

VOLUME 4, ISSUE 1, 2021, $24-48$.

www.egyptfuture.org/ojs/

\title{
Challenges and Prospects of Sustainable Development of Ecotourism and Handicrafts in Red Sea
}

Badawi M.ISMAIL*

Dean of the Faculty of Archaeology, Luxor University, Egypt.

\begin{abstract}
Ecotourism is a form of tourism involving responsible travel to natural areas, conserving the environment, and improving the well-being of the local people, its purpose may be to educate the traveler, to provide funds for ecological conservation, to directly benefit the economic development and political empowerment of local communities, or to foster respect for different cultures.

Red Sea area considers one of the richest district in Egypt, contains natural tourist components such and ancient quarries and archaeological mines in Wadi Hammamet and Qusier.As well as Marine Sports, Beach tourism, Medical Tourism, Recreational tourism, Historical Tourism, Religious tourism, Safari tourism and adventures in addition to; nature reserves and beach islands such as; the Jiftun and the Shdawan Islands, area of the Abu Manqar islands rich in mangroves, the area of Dasha al-Dabaa, Safaga Island, Utopia Island, Umm al-Jorasan Island, Al-Zubarjid Island.

Red Sea is Known for a very rich tradition of craftsmanship; there are various and different traditional handicrafts such as; leather products, Palm Industries, traditional folklore jewelery industries of silver, Wood Industries, household decorations, Kilim industry, manual industries of plants and natural rocks in the areas of; Halaib and Shalatin, Marsa Alam , Hamada, Abu Ghusoon and Ras Banas, Qusair and Safaga .

This paper is discuss the challenges and obstacles facing the exploitation of the natural and human components to develop and develop eco-tourism in the Red Sea region, which helps to increase the national income and support sustainable development in the region. but the development of handicrafts has encountered many problems including the lack of a specific market with adequate stores, lack of managers who deal with message delivery collection of products, and inability to find new markets at home and abroad. Development of handicrafts in the Red Sea area and their reality and perspectives are reflected in the present study. The results revealed that although artisans in the Red Sea area try hard to develop handicrafts but it needs a great support to move forward and compete with other countries.
\end{abstract}

\section{Keywords}

Handcrafts, Ecotourism, Sustainable development, Marketing, Red Sea, Egypt.

\section{Introduction}

\section{Introduction about the Red Sea Governorate:}

The Red Sea Governorate is one of the most important governorates in Egypt ( Map.1). Red Sea coast stretches for $1080 \mathrm{~km}$, from the Gulf of Suez, latitude 29 north, to the Sudan border at 222 latitude. And the Red Sea Governorate of the coastal governorates of the Arab Republic of Egypt and an area of 130 thousand km 2, which represents $1 / 8$ area of the Republic and the area is limited between latitudes $(29,22)$ and bordered by the Red Sea coast to the east about $(1080 \mathrm{~km})$ and bordered on the west The governorates of Beni Suef, El Menia, Assiut, Qena, Aswan, and the northern governorates of Suez and Giza.

Main cities: Ras Ghareb - Safaga - Quseir - Marsa Alam - Shalatin - Halayeb and Hurghada, which is the capital of the governorate

\section{Economic Importance and Mining Prospects:}

The governorate is one of the most important governorates of Egypt for mineral wealth because it contains the 
vast majority of metallic and non-metallic materials and ornamental stones. The wealth is as follows:

\begin{tabular}{|l|l|}
\hline Petroleum & $\begin{array}{l}\text { The governorate produces 76\% of the Republic's production and is concentrated in Ras Ghareb, } \\
\text { Al Jumsha and Ras Shuqair. }\end{array}$ \\
\hline Gold & $\begin{array}{l}\text { In the area of Abu Marwat / Ras Gharib - Zaatar and bath / Safaga - Um Rouss and Um Samra - } \\
\text { Baramia and sugar - Umm Hijab / Marsa Alam - Aminit / Shalatin. }\end{array}$ \\
\hline Iron & $\begin{array}{l}\text { In the area of Abu Marwat / Ras Ghareb - Wadi Karim / Qusair - Umm Khamis Jabal Al Hadid - } \\
\text { Umm Nar / Marsa Alam. }\end{array}$ \\
\hline Marble & $\begin{array}{l}\text { In the area Road of Sheikh Fadl - Valley of the Bear / Ras Gharib - Wadi Duaij - Wadi water - } \\
\text { Umm Safaf / Marsa Alam. }\end{array}$ \\
\hline Phosphate & $\begin{array}{l}\text { In the region, Ras Jamshah / Hurghada - Umm al-Huwaitat / Safaga - Hamrawain / Qusair - } \\
\text { Umm Reja / Marsa Alam. } \\
\text { stones }\end{array}$ \\
$\begin{array}{l}\text { Agate (Valley Waseef / Safaga - Valley of beauty - Abu Suwail Marsa Alam) - Kurtz (Wadi } \\
\text { Soliman / Qusair) - and Zmurd (Zbara - Skate - Umm Harba / Marsa Alam) _ Aquamarine in the } \\
\text { valley of Algemal and Abu Rashid. Other materials such as talc - sand - white - copper - granite } \\
\text { - asbestos - mica - gypsum - aluminum. }\end{array}$ \\
\hline
\end{tabular}

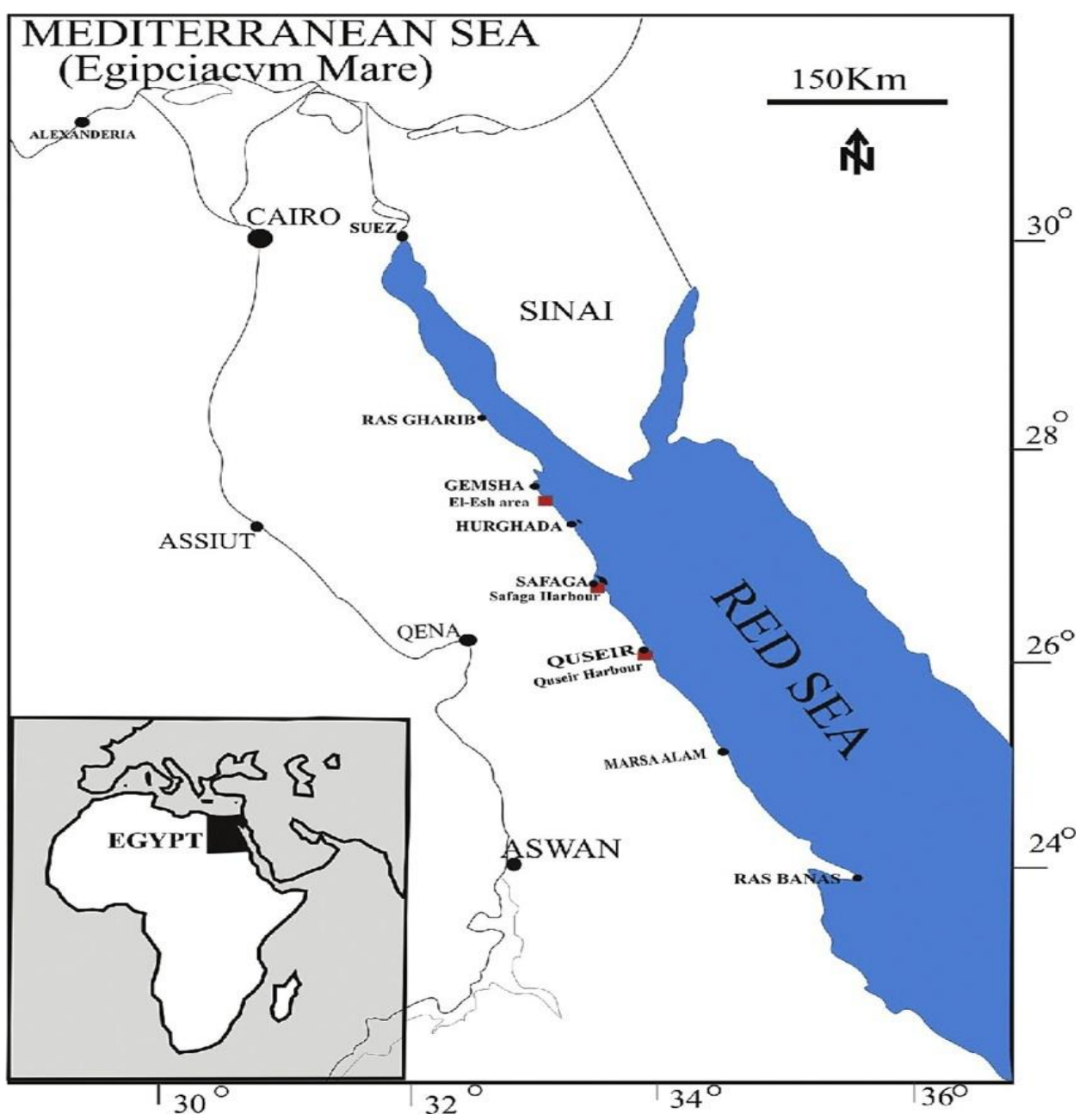

Fig.1. Map of Egypt includes studied area. 


\section{The importance of Tourism:}

The Red Sea Governorate is considered the governorate of hope because it enjoys the bright sun and mild climate throughout the year as well as the charming nature and soft sand in addition to the sea water contains water and coral reefs is truly a wealth and the city of Safaga is characterized by radioactive sands that treat psoriasis and rheumatoid diseases. There are also a number of pharaonic, Roman, Coptic and Islamic monuments as follows:

Pharaonic and Roman: Um Fawakher area - Wadi Hammamet $235 \mathrm{~km}$ south of Hurghada. Coptic: Monastery of Anba Antonius $50 \mathrm{~km}$ north of Zafarana and Monastery of Anba Paula $95 \mathrm{~km}$ north of Ras Ghareb. Islamic: Tomb of Abu Hassan Al-Shazli - Wadi Hmithra $150 \mathrm{~km}$ west of Mursi Alam - the Islamic Tabiya in the short and the port of Aisab Bahlib South. Because the governorate enjoys this climate and the various tourism elements, the activities of tourism patterns are as follows (Beltagui, 2001 ):

\section{Marine Sports:}

Beach tourism, diving, sailing and fishing. There are 150 dive centers in Hurghada and Safaga.

\section{Medical Tourism :}

The Red Sea climate is characterized by dry air throughout the year and the bright sun, as well as therapeutic possibilities given by God to this region of black sand, warm water and sunshine, especially the Safaga area where scientific research has been conducted, which proved to be effective in some diseases (Ngai,C.W,2009).

\section{Recreational tourism:}

There are the Jiftun and the Shdawan Islands, area of the Abu Manqar islands rich in mangroves, the area of Dasha al-Dabaa, Safaga Island, Utopia Island, Umm al-Jorasan Island, Al-Zubarjid Island and two brothers.

\section{Historical Tourism:}

The history of the governorate dates back to the Pharaonic era, whose effects are in the area of Umm alFawakheir in Wadi Hammamet (Edfu Marsa Alam road). It dates back to the Roman Ptolemaic period, the remains of which are in the generation of Abu Dukhan and the Islamic ages.

\section{Religious tourism :}

In the Christian era, the Eastern Desert was a refuge for the monks. The oldest monasteries were the Monastery of St. Anthony and the Monastery of St. Paul. The Islamic Monument is the tomb of Sheikh Abul Hassan AlShazli in Wadi Hmeithra.

\section{Safari tourism and adventures:}

This type of tourist is spread in the governorate, where it has a huge range of mountain ranges suitable for mountain climbing, in addition to the existence of many valleys suitable for riding and beauty and there are many types and races that help to sport cars and motorcycles Rally Pharaohs.

\section{Handicrafts and old roads in the Red Sea:}

It is worth noting that the traditional handcrafts of the Red Sea are almost exclusively through the old commercial routes of the Red Sea. It can be summed up that the crafts of heritage dimension are actually confined to the southern Red Sea with a few of them in the northern region where the concentration of most ancient traditional tribes with long history in Egypt is basically stable south of the Red Sea.

\section{-Cultural heritage in Red Sea}

The old commercial routes in the Red Sea are:

1 - The old pilgrimage route (Qeft- Qus Ayedab road port of Ayzab south of the Red Sea) 
These roads represented the sacred crossing of the Egyptian pilgrims, the pilgrims of the Arab Maghreb and Andalusia, and the pilgrims of West Africa during their pilgrimage to Makkah, where they were entering Egypt through the western border and then riding the Nile to reach the city of Qift or Qus in southern Egypt, They take the land route to the city of Qusayr or to Aizab, which was the port that transported pilgrims to ride the sea and go to the Holy Land to perform Hajj.

This is in addition to the interest of the state in the road networks for pilgrimage, where the pilgrimage to Mecca in particular became the focus of the eyes of kings due to the legitimacy granted to those who monitor them and the organization of means of transport and the provision of pilgrims to the holy places in addition to control of these roads remained a source of political competition And religious communities among different regional authorities in order to attract trade flows and the resulting economic and financial resources.

2 - The way of the old maritime trade (Qatf Hammamet Qusair- Qusair)

Old Mines Trading Road (Qena - Wadi Qena North of Hurghada)

The Red Sea Desert is a distant history dating back to the prehistoric era, an area discovered by the ancient Egyptians and still evoked in the valley of Hammamet (Hikade,2006). The Red Sea desert was also a major link between Pharaonic Egypt and Africa for the exchange of goods, especially during the reign of Queen Hatshepsut, At the time, Thaglo was named as a base for the launch of its maritime voyages for the ships bound for the country of Punt to fetch the timber, where Dr. Abdel Moneim Abdel Halim, professor of Egyptian archeology at the Faculty of Arts, Alexandria University, was found while digging in ( Jasous) valley located 60 $\mathrm{km}$ north of An ancient painting that records the departure of an Egyptian mission to Puntland. The name of the sites taken by the mission includes a port of take-off and an inscription on the rocks (Qeft-Qusair), which has a length of $180 \mathrm{~km}$, containing 2,300 engravings engraved on the rocks on either side of the road. The Eastern desert continued in the Ptolemaic and Roman times as a source for the import of stones and the extraction of gold and minerals because of the richness of the Red Sea Desert with various natural resources and treasures. The great need for such wealth was the port of Qusayr, an important port in the Roman era. It was known as Tau, as it was known in the Ptolemaic period, (The white port) and was connected to Bkeft and Wadi Hammamet and still rocky preserved inscriptions dating back to the Roman era and Greek as we see in (SafagaQena) in Kilo 40 of the city of Safaga Diocletian famous Roman site and Station known as the wall of Qena Rye is a Roman station located $30 \mathrm{~km}$ from the city of Qena on the road (Safaga - Qena) in addition to the Roman road networks that were planned in the era of the Roman Empire. The Torino Museum in Italy still retains the original maps of the Roman road networks in the Red Sea desert by the German world Prof -Alan.

\section{Protected areas and natural reserves associated with handicrafts in the Red Sea}

\section{Wadi Al-Jamal Reserve:}

Wadi Al-Jammal Reserve is a desert reserve located in the southern Red Sea Governorate of Egypt, covering a total area of $7450 \mathrm{~km} 2$. It comprises 60 kilometers of coastline, $60 \mathrm{~km}$ wide, $50 \mathrm{~km}$ in the eastern desert mountains and the remaining $10 \mathrm{~km}$ in the Red Sea. A nature reserve was declared in 2003. The reserve also features geological formations filled with precious metals such as emeralds, ornamental stones, feldspar, lead and manganese. It also has traces of ancient warpoles, castles, gold, precious stones, granite and emerald sites near the Skate Valley, where the emerald stone, the only source of the stone during the Roman Empire, has the largest emerald mine in history. It is inhabited by inhabitants of the tribes of Ababdeh and Bashariyya, who belong to the oldest peoples living between the Red Sea and the Nile. Their activities are concentrated in grazing 
and exploitation of plant species in food and commerce.

\section{Jabal Olba Reserve:}

The reserve is located in the south-eastern corner of the Halaib Triangle. It is an area of 35,600 square kilometers, located between 22 and 23.30 and long lines 34.5 and $37 \mathrm{~km}$. The reserve contains many natural, human and cultural resources between wild life, medicinal and economic plants, local tribes, cultures, pharaonic monuments, ancient drawings, geological and mineral resources, water resources from wells and springs for fresh water, and the Red Sea enriched by large marine resources of coral reefs, marine grasses and rare marine organisms (Wilson, A.M. ,1999). In addition to many Red Sea islands within the limits of the reserve, which contains sea turtles and many species of rare birds and migratory birds and species of mangroves with great environmental and economic value (Samy,.M.,etal.,2011).

\section{Ecotourism and Communities in the Red Sea}

\section{The tribes of Bashary}

The people of the Beja have been living in this area for thousands of years, practicing grazing, moving behind the pack and farming, and growing corn and millet, the grain from which they make bread. And agriculture is based on the rain, which tells their land and drink grazing animals, dried wells and rain stopped for several years, as happened during the past years died planting and supplication and the people of the tribes to live difficult. So the Bejaoui live a tough life on a rain-hard ground, although the cave is rich in many minerals that brought adventurers and colonists to exploit and was coveted them. Bejaoui is small, with a light body. His skin is reddish with curly hair. He is characterized by toughness, strongness and strength. He lives in isolation in his area, so he has preserved his heritage and his offspring. The country has been subjected to many campaigns, the Pharaohs, where they searched for gold and the phantom of the elephants as well as gold and the Shebaa and Hamir in Yemen for trade and profit. He was also subjected to the British who used cruelty and machine guns to subdue them.

\section{The tribes of Ababdeh}

Ababdah of the tribes of weight and status in the Red Sea and Aswan are sons of Abdullah ibn Zubayr ibn alAwam. And they speak Arabic language and maintained it over the years, after their departure from the Arabian Peninsula and mingled with the sons of Bashariyah and became the closest to them as they are cousins who have maintained their Arab identity and did not mate with the Negroes and the most famous tribes of Alababda: Almalkab and slavery and Shanter. All the branches of ( Al-Ababdeh) were displaced to the Nile Valley and merged with its inhabitants except for the tribe of (Ashbab) who still inhabit the Eastern Desert starting from the line between Qena and Al-Qaseer until the last border with Sudan. As the tribes grew and spread, the (Ashbab) tribe itself divided into several tribes. The tribe of (Alababdeh) in general spread throughout the governorate from (Ras Gharib) north and (Halaib) south and the number increases as we head south. They work in cities in the oil, mining, fishing and grazing sectors in the south.

\section{Tribes Almaazh:}

The attribution of the sons of Atiya to Maaz bin Asad bin Rabia and Leaaz three sons are Attia, Akil and Khamis was Attieh is the largest children Maaz, the name of Atiya over all the sons of Maaz.

\section{Beni Attieh in Egypt:}

They are spread in many governorates of the Republic, where the name is spread in the east, Giza, Menia, Beni 
Suef, Qena and Aswan.

\section{Al-Maazah in Red Sea Governorate:}

The tribe of (Maazah) spread from (Zaafarana) to the north and the largest gathering in the well (Boerat) to the of (Al-Nasr) village in Safaga Qena. Al-Qusayr desert and the eastern desert between the sea and the Nile Valley are working on grazing, some in safari stations or in the guard work of mobile networks or mines and quarries. The ( Maazah) tribe is divided into the following branches in the Red Sea:

Al-khashman: From Zafarana to short

-Castles: Ras Ghareb / Zafarana

-Asayat: Sheikh Fadl Road / Ras Ghareb, Beni Suef and Minya

- Alshahban: links on the grapevines and shrubs and in different places.

\section{The tribes of $\mathrm{Al}$ - Rashandivah:}

\section{The tribe of Qazaiza and Arban al-Rashandi:}

Of the major tribes in the Red Sea, especially in Hurghada and live in the neighborhood of Arabs known as Dahar and one of the first tribes that were presented with Juhayna and practiced fishing craft. And are located in Hurghada, especially the last branch is the Rashandip and work in fishing and tourism. The tribe of Qazayzeh tribes of the known in the north of the Arabian Peninsula and attributed to the most courageous Guthani are cousins of the tribe of Abas Ghatfanieh and were included under the tribe of Znamat tribe of Bani Fazara Ghatfanih were known as the Qazayza relative to Maan bin Issa bin Din al-Qazzaz Alshaji as mentioned in the book Genealogy.

\section{Tribes of AlAshraaf, Juhaina and some other tribes:}

(Juhaina) is one of the largest Arab tribes in Hurghada. A number of them came from (Amlaj) in Hijaz to (AlGweih) and then Hurghada. Some of them came from Hijaz to the Red Sea and a number of them came from Hijaz, the first home of the Arab tribes that came from Hijaz. Many of them work in fishing and tourism.

\section{Al-Azayzeh in the Red Sea:}

The sons of (al-Azayzeh) are in Ras Gharib and the majority of them are in Hurghada in the (Arab neighborhood) of Dahar and Qena in the western region of (al-Tuwairat) and (Dandara) and in the east in (Hager al-Qal'a) and (Qift) and in Aswan in Ezbet al-Arab in Kom Ombo.

\section{Rashaidh:}

The (Rashaydeh) tribes belonged to Rashed ibn Rawah bin Malik bin Ghaleb bin Quta'a ibn Abes. Some of the references said: Their Attribution is due to Rashid Bin Bajad bin Malik bin Ghalib bin Qtayya ibn Abes. Rashaida is currently deployed in most Arab countries, where the vast majority of the Rashaida are in Sudan.

\section{Rashaida in Egypt:}

They are located in the Nile Valley in Aswan, Kom Ombo, Edfou, Qena, Sohag, Assiut and Sharkia.

\section{Rashaida in the Red Sea:}

They are located in the Shalatin area.

As they are nomadic tribes between Egypt and Sudan, although they claim it because of their long stay in the region and confirm that they are Egyptians and attended the Arab conquests and work in the camel trade between Egypt and Sudan and reside in Egypt with temporary permits.

\section{The tribe of Hweitat:}


The tribe of Hweitat of the great tribes in Egypt, Jordan and Palestine and the tribal ratios are attributed to the whole family of The Ashraf Hussainian are from the offspring of Sharif Hweit bin Trad bin Mishari bin Zakaria bin Mousi bin Sanad ibn Tufail bin Mansour bin Jammaz (Prince of Medina). The families of the Huyatat in the Red Sea in Hurghada in Dahar in the neighborhood of Arabs and in the Sakala.

\section{Al-Jafra:}

In the book of Arab tribes in Egypt in the first three centuries of migration, it was written by Professor Abdullah Khorshid al-Bari. The Jaafara are the sons of Jaafar al-Tayyar ibn Abi Talib from Bani Hashem ibn Abd Manaf who migrated to Egypt from Mecca in the tenth century AD, ie between the late third and fourth centuries $\mathrm{AH}$. The Jaafara section is concentrated in Ras Ghareb and Hurghada in the Red Sea Governorate.

\section{Section I: Handicrafts and Ecotourism in the South Red Sea:}

\section{Halaib and Shalatin:}

(Shalatin and Halaib) were known recently in the last 20 years as many of them. As the people know it, the name came from Shalt I Bir and Shalatin, a group of wells where it was a very important station for tribes and camels for passage and crossing through the eastern desert and its port on the Red Sea. It is said that the name of the city of Halaib came from the Olib tree, which is known many near Halaib, but away from the names historically, these cities were known as an important part of the journey of the pilgrimage through the road of Ayeab, which starts from Qeft and Qus to the north of Halaib at the port of Ayahab through many stations Through the eastern desert and its wells and valleys. The area is mainly inhabited by an area of up to half the area of the Eastern Desert, (Ibrahim,Z.,2009) almost from the Qusayf Qatif road to the borders of Egypt with the Sudan, different tribes are Alababdeh and Basharyh and Rashaydeh and the most important villages and cities are the most brilliant and modern and Abasafh and Qambit and Lailah and Abu Hadid and Aldeib Amihib, Aydab, Sararah, Hadarayeh, Idlib, Abomad, Bernice, Al - Khmera, Chemed, Abu Ghusoon, Hamatah, Al Qahtani, Sheikh Al - Shazly, Hafeet, and many small villages or gatherings for the population through desert valleys. Halaib and Shalatin are the most important nature reserve in Egypt. They are the protected areas of Jabal El-Taba in southeastern Egypt in the Red Sea as an integrated environmental system inhabited by the local communities of the tribes of Al-Ababdeh and Al-Bashariyya in the Eastern Desert. They depend mainly on grazing in the valleys of the Eastern Desert. The Ababdah and Bashariyya have many of their own handicrafts and crafts that are distinguished by the nature of the mountainous nature in which they live and the environmental conditions surrounding them. There are more than 350 masters in 5 scattered communities working unorganized in those manufactures of twigs, skins, wood, beads and pottery. Women produce the southern Red Sea handicraft in limited quantities as a shift to household responsibilities. The products are primarily of low value such as beads, leather ornaments, beads, fashions and bags of leather, traditional products such as bling, woven bowls, woven carpets, and braided leather work. The traditional products are produced mainly for home use. Jewelry, leather bracelets and beads are produced simply as distractions from domestic businesses. Products are rarely sold. Difficulties are reached by producers, buyers and the quality of the products. Most of the products sold by the region's retailers are from Aswan or others. Of the areas in Upper Egypt. This area was known by many traditional industries for thousands of years for the nature of the desert region and the need for man to exploit all his local resources to serve his daily life of mackel and drink and protection and trade. The region knew handicrafts such as palm, skin, palm fronds, ornaments of beads, Beads, wood and rock drilling. 
On the one hand, it is important to first come from leather or leather industry of animal skins for the manufacture of leather products, wonderful and distinctive and high quality in terms of craftsmanship or variety of products such as proximity to water and proximity to ghee or animal fat and wallets for men and bags for men and women and belts for daggers and swords and Sleeping pads and shackles for keeping or suspending food in the house or tent, and also hand bracelets and protection for men and children, and sometimes for the bells for the Second is followed by the degree of importance wood. It is made of wood, especially wood acacia trees or cactus or as known by the Bashari name of the Saqqnib or as known by Alababdh name of the Samar or the wood of sugar and salts and Alall made of it most needs such as Hrkak or Hodge camel for the relay and also bowls or dishes of wood to save the milk of the bell and Goats and food, as well as sticks of all kinds and also to grind coffee beans to prepare coffee cheese for traditional known to all tribes and the people of the region with its distinctive rituals and also made them for women's ankles and also bakeries and also Msandr head or hands used tents for comfort when receiving guests or sleep is Similar in shape The ancient pharaohs also made an important part of the music of the tambour, the traditional playing area, which was decorated with leather, and also made of wood, the houses as a whole, walls and bishop, as in the whole house of the mountain of the tribe of the distinctive tribes of the Bashari or the structure of the house covered with sand, For the tribe of Alababdeh and although the agriculture was not known on a large scale in the area, but he recorded the use of agricultural tools industry of lumber, such as sowing seeds and prickly wood saffron where used with the methods of agriculture there, which relied heavily, such as the first agriculture of the ancient Egyptians on the flood where The population is waiting for rain and floods in the valley and after several days sowing the grain using a swastika such as a washer and waiting for a period to exit seedlings and then collect the crop after maturity and was the most famous types of crops are hawk, barley and watermelon diseases of envy or diseases, and also the shoes or light sandals that are distinctive, similar to the full complement and the same relationship as the old Egyptian pharaonic shoes ... Made $\mathrm{N}$ leather musical instruments such as Tmburh and also carapace fighting and celebrations, such as dances, traditional and making them handles for daggers and stick as they are made ladies costume leather either for decoration or for the newborn and children to protection from disease.

Third: is the importance of the craft of fronds which, although historically, environmentally and geographically, there is no significant recording or spread of palms in the south of the eastern desert to the border between Egypt and Sudan, except in several areas and trees and it seems according to the ancient travelers that trees planted recently of 100 years Or slightly more than in the delta Valley of (Al jemal) or the valley of (Abusafh) and some small valleys so, although there are no trees, but many Nakheel, it seems with the contact with the tribes of Ababdeh and Bashari with the Arabs and the people of South to ascend in particular Aswan and some areas of Qena like Esna had brought with them the raw fronds and helped touch In addition to playing the historical role between the movement and travel of the tribes of (Bashary) through Egypt and Sudan in the great friction and transfer of experiences and character and skills such as Palm palm trees from the tribes in the west and north Sudan, such as (Nuba) And (Kordofan) famous for this craft, which is evident in the distinction of older women in the tribes of Pashtari Ali ladies Ababdeh in the manufacture of different forms more literal in the debate Wicker and variety of products and control the distances of connection and measurement and blending the skin together and the form of the final product and that These differences have now diminished as the generation enters The new that you learned about the hurry and without the full transfer of traditional knowledge associated with it from previous generations and that it was the harbinger of the existence of the last 
generation of wise men from the tribes, even if the number is few but they have a great enthusiasm to take the grandchildren and their children to learn that craft from an important perspective It is the heritage of their ancestors that must be preserved not only from the perspective of the material income, which no longer gives its value behind those handicrafts now, unfortunately, especially with the retreat or absence of tourism mainly in the area except in Marsa Alam, $200 \mathrm{~km}$ away from their areas, Use the old tools of the fronds in their homes For the attention of the new generations of its products and heritage thoroughbreds.

The fourth is the importance of the industries of wool and sheep, where, despite the few of those wools, but they were keen to exploit, especially by the leader of the house Bedouin women, who kept all the natural resources for reuse, and the creation of tools spinning and weaving where they use the tools very primitive It is four wooden bases or branches of trees placed horizontally and tightened by using yarns yarns of wool to make a heavy and large pieces of tents hair of goat hair, but those letters to a large extent did not know the tribes Albja, but Amiz and months are the tribes Albabde especially in the middle Eastern Desert The areas of Abraq, Shalatin, Hofat, Wadi Al-Jammal, and Al-Bashariyah are custom-made for them.

\section{Socio-economic situation of the craftsmen:}

Most of them are women by hand crafts (95\%) are women with low educational level (illiterate or dropouts from primary and secondary education) from the tribes of Ababdeh and Basharya in the Eastern Desert in the southern Red Sea in the areas of Shalatin, Wadi El-Gammal, Mers Alam, Hafeet and Aburamad, Abraq, Bernice, Qalqan, Abu Ghusoun, Hamata, Little Al-Jaraf and Cheat. They are women who have no source of income. Many of them are women who are dependent on their families or are married to couples working in the field of grazing or fishing. They have no fixed monthly source, And most of them monthly income of the family as a whole not more than 120 pounds per month. There are more than 350 ladies in 5 major groupings in the region. They work in an unregulated fashion in these manufactures of twigs, skins, wood, beads and pottery. The women of the South Red Sea region produce handicrafts in limited quantities as a conversion to domestic responsibilities. The products are primarily low-value such as beads, leather ornaments, beads, manufactures and bags of leather, traditional products such as woven carpets, rugs, and braided leather work. Traditional products are produced mainly for home use and jewelry such as bracelets produced for decoration as a distraction from home business.

\section{First: Leather industries:}

The women of the Bejaoui and Abadi in halaib and Shalatin do many different handicrafts and distinct.

Because the Halaib and Shalatin is a desert area and intersect with a coastal strip on the Red Sea, the eastern side was used by the people of animal leather living in this area in all their tools (Sanyal, S.etal.,2010), whether these animals are wild or pet, where the man took the leather of the carcass and after commenting on The branch of trees is spread on a high hill and sprinkled with salt and left in the sun to dry and then comes the second stage, which is the dab of the skin using the "Cradle" is an acacia tree spread there and this is done by letting the leather soft and free of any trace of meat and blood and be soft texture As a cloth often uses a coloration The color is rarely used as it is used by men in the manufacture of slippers, ice creams, household appliances and some decorations. The red color is used as a product for mixing some grains and salt, then adding wood dust. The yellow color is mixed with ginsball paste and lemon juice. The green color is a mixture of copper wire and iron plate. The leathers have many different uses after being processed and dyed to be decorated by digging into the leather so that the thick leather can be drilled and some of its plates removed and treated with drawing and 
engraving either by honing some parts of the suede or by using some colored fabrics after cutting to complete the form to be drawn to form an area of The cloth is interspersed with an area of leather and sometimes it is decorated with a piece of sheep leather. These industries are based on the leathers of the animals, such as the goat and the sacrificial animals, after it is used. The tanning seeds are used in the seeds of the loan trees and some other dyes imported by caravans from Sudan or Esna and Aswan. The tanning process is done with salt and lye powder, (The loan is a fruit produced by trees of the Acacia), sharp taste and smell of smell and used by the people of Egypt and Sudan in municipal medicine and tanning and other uses were tanned skins, whether local or imported from Sudan, making them out of everything until the shoes embroidered with beads sometimes, Pass Bagh to the second phase and is the processing and final design of the product, there are three cases, either full use of tanned skin or cut to cut each piece to use in the manufacture of a particular product or cut to work segments within the industry, hand tools for certain. In the first case: the use of the pigmented skin of an animal to make it close to water or to margarine or fat In this case it is fully used as it is after the cleaning. The leather is covered in ponds filled with the loan and left for a few days - and then suspended one after the other in special bearings for weaving the wool and then tapping to close the openings of the head, legs and hands as required. Cows for the manufacture of what is known as salsa is the leather of cows that are not accustomed to the tribes of Ababdeh or Basharih to raise them only to raise goats and sheep, which makes the fords or near a small water or to bring Yah of the well or to save margarine or fat.

In the second case, the leather is cut into small pieces after tanning to be used in the manufacture of bags and purses, or was made out of the shoes of the type sandal desert similar to the style of the sandal or ancient pharaohs.

The third case the leather is cut with a sharp blade such as a small knife sharp to strips length along the length of the skin and the width of the tape $\mathrm{cm}$ to $2 \mathrm{~cm}$ and after cutting the strips like wicker in the same way to manufacture bags or tables or bracelets or different types of jewelry or household items Such as the nexus of the house tools also enter those strips with the same wicker to work products of wicker and leather together and is the unique distinctive character of the tribes of Abaydah and Bashary in all of Egypt and there is no other place in Egypt have all that skill and skill in Mix the skins with the bling together in the same product.

\section{Examples of some leather products in the Eastern Desert:}

Al-Qurba: is a jerba and is called an Esr and is used for water conservation. It is made of goat leather after removing the hair and dabbing the skin. Durakat, which is a bucket made of sheepskin, has two hands and a top that connects ropes to raise water from the wells. To save money and place to put the dagger is also made of leather and decorated geometric shapes, for women to be a bag to save money. A leather bag is designed to Ladies put out their personal items Al-Qurba is made of the suede to save traditional coffee equipment and carry the hodgepodge camel when traveling behind the grazing in the desert. A mattress made of "Imbast", a sheepleather pad embroidered and stuffed with camels or smart-smelling wood Called "Hendect Hiraj "made of sheepskin used in many things to carry personal belongings on the camel.

Marabou: It is made of goat leather goats is the best and has a mouth is the place of the neck of the animal originally and tie the two men and hands with a rope to suspend the cough later and the water is the same as the full cough, but the cough on the tool used for milk and water to keep the milk .. For the purpose of extracting the butter from it, where the fresh milk is placed before that in a special vessel and covered until it clotters and becomes thick. Then put this milk in the cough and blow the cough and then hang on a pyramid of three sticks 
and push forward and backward (convulsion) until the butter is separated from the milk, Buttermilk), and then isolate the butter by extracting it By hand, to make the municipal ghee or to be used as it is after it has been melted. The camel is the most important legacy of Halayeb and Shalatin, it is not only the most important means of transport in the desert is the ship and the military vehicle, says artist Abu Hassan Tkroni It is the source of his livelihood and the elephant is very high for these tribes in terms of their presence, they keep them and nurture them to rely on them in everything and they decorate them and put on the neck "Marhad" made of sheepskin and sheep to protect from envy It is a part of the camel's camel parts of the natural environment, and "Mkhlalat" camel decoration during the camel race, which is held in the wedding ceremony is made of wool and colored cloth decorated with a scarf and is part of a camel. In the celebration of the marriage, the Bedouin is keen to beautify the camel and decorate it with all the means of the environment. The purpose of the decoration is to protect the camel from the harm of evil spirits and is decorated with beads, leather, and wool. Of the skin stuffed with ostrich feathers so as not to appear camel hump and wrap "Mahakob" around the waist and bottom of the lamp and decorate the head of the camel "Haskat" is a "belts" of the leather hung Kaljam to lead the camel and flared with regard to the gambler of the skin is occupied in the form of trumpet and on the sides of the camel next to The neck and two are after the center and stretched out Li on the Hodge.

\section{Second: Palm Industries}

HOne of the most important works of women in the region, is the craft of wicker or wool, which was considered one of the most important necessities of life, which provides most of the needs of the family and home. These products excelled by the women of Shalatin and Halaib, Abromad and the villages of the eastern desert, southeast of Egypt, Despite the lack of full prevalence of palms, only, a small oasis called "Abu Saafa" in the village of "Abraq" village, inside the eastern desert, but they relied heavily on the Wicker coming from the Sudan, through the market of Shalatin or Aswan, and sometimes the wicker coming from the countryside, such as Edfu and Kom Ombo. They call the areas of Edfu and Kom Ombo the countryside, because of agriculture on the banks of the Nile, and are versus to the desert as it without planting.. The main tools in the manufacture of wicker, rely on the hands, teeth, and the foot fingers, and sometimes a knife is used to cut the threads of the fabric of the palm and the appendages according to the size of the product baskets or mats or dishes, and also of the most important tools is the sewing and the needle, it is like a needle, but large in size and has a small handle of wood in a cylindrical shape as a screwdriver to insert the wicker to mesh slices wicker in a spiral to take the shape of cylindrical or rounded in the final form for manufactured product.

\section{The stages of the palm industry}

Prepare a container in which the palm leaves are immersed in water for hours to get wet, strengthen, be soft , and easy to use, and to be formed in braiding or to tie the wicker together in the baskets forming the slices from which the products are made. The women collect palm fronds and make it, by hand, in a manner of Wide braiding The width of the cue varies according to the type of production. The leaves of wicker intertwine with each other in the braid after turning to white as a result of exposure to the sun, the manufacturing begins by making a long- wide braid and Consistent color. The width of the cue varies according to the type of production. The greater the width, the greater the number of wicker papers used and the industry becomes more difficult. After the manufacture of the braid, the wicker is formed by using a wide, long needle and a line of wicker itself enters as an internal filler between the spiral wicker and spiral wrap until the final product is formed. It is known that women in the region use only white paper from palm trees, and do not use the palm or yellow green paper 
of palm trees, because of the braid that manufactured from this palm is large does not suit them and does not fit the heritage of the region, only the big green paper was used in the industry of so-called brush and is a kind of mats used for mattresses and tents and also to build a variety of houses for the tribes of the tribe called "Bait al-Barsh." It is known that the wicker is two types:

The first type is the core of the wicker, The core is characterized by its whiteness, Which increases by exposure to the sun and by decreasing its size, flexibility, ease of formation, and solidity, and is used for a certain quality of production.

The second type is the rest of the leaves of the ordinary palm, the leaves are more rough and tall and are immersed in water to make it easy to form. It is noted that the palm products of the women of "Halaib and Shalatin" are characterized by accuracy and beauty, and do not differ significantly from what is produced by the characteristics of "Saff Dom" in the regions of Sudan.

The women of "Halaib and Shalatin" did not know coloring or dyeing the wicker from the women of Nubia and only be satisfied, in the white or milky color of the wicker, and its nature that tends to yellowish brown after a period of time. It may be due to the lack of historical knowledge of the skills of pigment, or the absence of plants such as nil or safflower, saffron, turmeric and other plants in the region, but they generally replaced the decorations with dyes, by decoration with ribbons of leather or beads, in a distinctive way, which gives the products of dishes, baskets, boxes and coffins or wraps in a wonderful and distinctive form unparalleled in Egypt for a craft or precision and mastery. The women did not know , as a Nubian, pigment the wicker by colors ,Green, Annabi and Purple that are called turmeric. This is further evidence that the Nubian man knew pigment and coloring from ancient times because it has its vocabularies in the language in addition to the archaeological drawings and colored writings that they left on the walls dating back to the pre-Christmas. In the south of the Eastern Desert there is no evidence and historical inscriptions on the origin of that art of pigmentation. There is also an important comparison between the wicker crafts in the ladies of "Halayeb and Shalatin" and Nuba ladies, when manufacturing wicker weaving and knitting it must be soaked yarns in the water to let him, whether the wicker ordinary or colored, in the case of Nuba, which the dye does not disappear with water. After softening the wicker it is easy to form and manufacturing begins with making a braid with the wicker. In the case of Nuba, the internal stuffing that surrounds the wicker is mainly from the Argonne or the stalk of palm which carries the fruits, that in Egypt is common in manufacturing the brooms. On the other hand, in "Shalatin" the Internal filling is the wicker itself, This means that the wicker wraps around the wicker and it is what distinguished "Shalatin" that the wicker braid is very narrow and its quality is high, and it is not too large for liquids and does not rot or affect the water easily. In the case of the manufacturing of mat of house, These mates are made from the palm, Which the women braiding a number of the palms around each other in a certain way, different in length and width as a required and needed, a long and wide cue is made and the width of the cue varies, and this is depending on the type of production. After making the braid, the wicker is formed by using a wide, long needle and a line of wicker slices, in the case of the "Shalatin", after preparing the required quantity, These braids are sewn next to each other also using the palms, and a long stalk of dates, as in the case of Nuba, Which were spilling into the yarns, before they dried in the harvest season and kept as raw materials for production, then it is sewn and intertwined with each other by wrapping them with the sponge in a spiral way with the other to take the shape or thing, as a required, whether it is a mat, scuttle, wicker house, and dishes for keeping or covering things, in Nuba. Sometimes the mat was made from the dum 
tree because it is stronger and more robust, and its size is greater than palm fronds, Thus, the brushes that are made from the palms of the dum trees are longer, and bear multiple uses, This type was preferred in public places, such as, mosques and sitting rooms, the palm of the dom was reaching either from Aswan or from Sudan, but in the last ten years decreased and increased its price, which affected the availability of hand products from it. It was also made from it a the hand fans for ventilation, during the summer days and types of baskets and brooms. From the palm they made also a prayer rug, which is used to perform prayers, and also they made a mat, where the women made a slices from palm braids to be a $10 \mathrm{~cm}$ in width, and it is longer than two meters. The slices are combined together in a round, rectangular or square shape. They are sewn using fine leather belts, and it is used to cover the structure of wood dwelling and also for sleeping . The Bedouin broom is a bundle of palm tied from the top of the hides of the skin and the red cloth and hung by the strands of fatigue and farewell and beads, And also there is a "Avolt" This avessel made of palm fronds, which is used in milking the camel, the bride's residence is not without the number of camel and adornment. Bags made of palm and shaper with leather and beads to put ladies' purposes in them. Bags made of palm with leather and form and beads to put ladies' purposes in them.

Musallaib: A rope of the palm connected by a Triple pyramid with a base in the form of a circle, and attached to the ceiling to keep the food and drinks out of the reach of the animals. It was as an old refrigerator, and made from palm fronds cut in the form of slices and then woven in the form of braid in Sequential and hollow oval shape, or from the palm in the form of ribbons such as the ones that make the mat, and put in it the piece with the thing to be saved, It is similar to circle shape, and then hangs on the ceiling of the kitchen with three to four ropes, including a close distance, with different size as needed. The hands are held in the form of a net and installed in the ceiling, and is used to save foods and milk, which protects them from cats and insects, and keeping them from entering the germs after covering them well.

\section{Third: traditional folklore jewelery industries of silver:}

(Al Shalatin) was known as an important station especially in the recent historical period for the movement and spread of many Arab and non-Arab tribes, such as the tribes of (Al-Bashariyya, Al-Rashayd, Biya) and other tribes. It was and remains the most important market and trading station in the desert East between Egypt and Sudan on the other hand and between the Eastern Desert and the Nile on the other hand, the market of (shalatin) distinguished spices and perfumes and leather and camels and flutes from some distinct types wood industries, although it currently suffered the last five years of decline. There is still a very small workshop on the manufacture of jewelry inherited by one of the manufacturers or dealers about his father. The workshop was specialized in the purchase of old ornaments of heritage or repair of the people or replacement or trade and the manufacture of some of the heritage of the region. Although most of the jewelery came either from workshops from (Cairo or Khartoum and Kassala in Sudan), only the presence of the workshop was contributed to find some kind of the beginning of the jewelry industry here in the region.

The workshop mainly make silver, which takes the form of (dallaeat), bracelets and rings of pure silver or is sometimes supplied with natural or semi - natural stones such as coral, turquoise or carneline and other stones, and that is currently used as artificial stones for the scarring or high price of natural stones. It produces costumes from the heritage of (Al-Bajeh, Al-Ababdeh and Al-Rashaydeh), which are known as the region.

At present, the workshop produces very little costume compared to the previous one and focuses only on some men's neighborhood in most of them such as the rings and the nature of the case for the tendency and the 
transformation of many or most of the women in the area about the traditional ornaments and turning them into a modern costume of gold and machinery in parallel, And the disappearance of the industry or the last remaining of the traditional jewelery industry in the region. In (shlatin) there is a trend and transformations economic and social change in large patterns of homes or clothing and fashion and its tendency to civil events or relatives of the city more than a traditional society has roots of heritage and tradition known previously known that not only affect the patterns or the existence of the manufacture of jewelry, but also on most of the traditional handicrafts in the region as one of the other important factors is the movement and abandonment of most of the tribes of (Rashaydh) from South (Shalatin) into Sudan and they were one of the most tribes and communities in the region associated with silver jewelery and natural gemstones and beads and shells.

\section{Fourth: Wood Industries:}

\section{1-Wood: Industries of the craft of the (Angarib)}

(Angrib) is belonged to Egyptian and Nubian cultures and civilization (Marwy) appears in an important way, whether in the tombs of the most famous Egyptian pharaohs, or it is a remarkable presence in many Sudanese houses or Nubia dwellings in Egypt and Sudan and the Uqrab is a bed Of wood and ropes from the palm fiber represents his superior pillow in a wonderful manner that the industry of Embrace is basically Dat assets due to the ancient Nubian civilization in southern Egypt and northern Sudan, that is a Nile. The origin of the word "Enqarib" came from northern Sudan. It was "extinct" in the Nubian language. It was invented until it became (anqrib) and was used in all regions of the Sudan and in ancient Egypt and was introduced from the land of Nuba to the country of (Al-Bajah) in the south-eastern desert. It is made from four lists and flogged with cowhide or camels, but during the reign of the Turkish sultan, the kings of ivory, ebony and gold were decorated. The main element is the " anqrib ", which is a bed with colored cords, made of four wooden panels and four wooden legs. The ropes are wrapped on it. The inner parts are covered with threads of twig in the form of upward and downward, and expand horizontally and vertically and rely on the stitch. It is famous for its old Nubia and Sudan people, and the mattress is made of (Imbast), which is made of goatleather, which is decorated and stuffed with camels or smart-smelling wood called "Hindtak", in addition to some home furnishings from "Hamel" Sheep wool cloth has been found carved on Dran temples as found in the tomb of Tutankhamun and other graves in Egypt continued the word Anqrib back to the word Naga Nubia or click and then carved to the word (Anqrib). It has been named several names according to the nature of the region is famous for the tribes in central Sudan in the name of the (Alqado-Alshabah) and the tribe of (Beja) in eastern Sudan and southern Egypt in (Sidab) and in the tribes called the Nile tribes called (Aknarib) have (Aldakak) and there are terms associated with the (Aknarib) like (Anakrib Moasher) any limp in the limbs and stuffed with pieces of wood to be balanced again and unfortunately in the recent period has become a threat to Egypt, Sudan and Sudan, but at the level of the world and neglected the use of people from the time ago, so that the Unisco listed in the legacy of material tools threatened by global extinction. It is known for the tribes of (Basharya), in the area of (Anakarib alHabbabi), and it is a conduit made of sticks after being brought out of trees in its form without the intervention of modern lathes. It is called longitudinal broth, broth and occasional sticks, and is woven from ropes. It is divided into two parts. The first is called the sea. It represents three quarters of the fabric. To tighten the fabric when it is relaxed and it is the feature of the hippocampal that the fabric of the separation (ie between each rope and rope there is a difference) to help enter the air from under the person sleeping on it and is usually loose rope which helps the person to sleep quickly. It has a great heritage value. The night before the wedding ceremony 
known as the "night of henna" and the wedding of the bride (each separately) is used to sit on the bridegroom.

\section{Manufacture of Anakarib:}

The stages of the manufacture go through the introduction of raw wood and then enter the saws according to sizes and then turning, followed by the stage of punching and assembly to the stage of the executioner and final finishing and add color and paste and then sandpaper and fill cracks. The neck is made of sardine and acacia trees and was made in its beginnings with primitive hand tools such as the arrival, which is a sharp piece of iron at the end of which is knocking on the wooden piece for comfort and then uses the so-called slingshot to break the so-called fork at the end of the broth for the installation of the neck and after that stage, With a substance of putty to deal with the cracks resulting from the expansion of wood and then stitched and installed and painted by the (gamalka) and installed either the machines were primitive takes time and effort and does not produce much for dependence on the hand and effort and activity of the worker and then comes the stage of weaving and be cow skin,( Anqabib) cod attributed to the skin or rope, which consists of palm fronds woven from the palm and then developed to the pin that is produced in Cairo and now to the use of plastic ropes nylon. The most famous names are the cod-encrusted cod of cowhide and short (hababy), which almost touches the earth and the neck of the kiln. And the Ankrib of the (jerrycott) or the Ankrib of the right that appeared in the seventies and the neck called (Abu Saruj) This neck is characterized by the length of his legs and wide capacity, but he stopped eating and was engaged in a machine called the bow and the evolution of the matter until the introduction of Lathes recently and is characterized by the light weight and beauty shape and ease of movement and uses multiple uses and comfortable in the case And in the villages they sleep without mattress. In (shalatin) was a great (Ankrib) and was its experts and manufacturers time that was a great turnout and was associated with many rituals and traditions of popular life of the community, but now there is only one person has a small workshop attached Porsche Smith works in the industry close to the The iron is made of nylon plastic, which has lost its distinctive shape and is no longer fully connected to the heritage of the Ankrib. Unfortunately, the socio-economic patterns of the population of the region and the emergence of different types of families and mattresses Spongy and cotton and otherwise considered that the (Ankrib) of the pen is no longer suitable for the modern home and that the reasons for the decline is the entry of the element of iron cheap and easy to manufacture as a competitor to the arrogance and the spread of iron industry and development And in different forms, which lost the neck of the (Ankrib) in the houses of Bedouin families in the region and also in Sudan and the introduction of new forms and designs in the design of the family is different from the shape of the (Ankrib), which did not develop.

\section{2-Wood industries, household decorations:}

That the materials of those wood industries are all extracted from the natural materials of the region, such as trees of high quality and resistance to natural factors and it is suitable for drilling and makes such as trees (Alsmer) and (Sial) and the ladder and the (Simok) and ten and sometimes (Hegelig) and wooden household tools that were made (in shalatin) stick used by pastoralists Of the population to protect and to take care of their camels and sheep, and they were made of wood and trees of peace, one of the types of trees scattered in the eastern desert or the trees of the (Seemuk) at (olba) mountain and made of wood after the crust of soft outer shell wrapped around the leg and then burning wood and engraving it or forming using the hot dagger and then dyeing a natural color of the plant extracts or glue to preserve it from decay and give it an aesthetic form.

And also from the wood inside the Bedouin or Bagawi kitchen, including wooden dishes for the provision of 
food, especially eating the broom called "Kopat" It is characterized by the edge to give the form of beauty and can hold the vessel from this edge by the young, and during cooking food uses the " From wood to Frak flour with water inside the pot and continue this mixture until the completion of maturity, and there are also some woodware used by women Pejawip for the preservation of their own perfume, including "sugary" and their wooden and blended with sandalwood perfumes and sweet smells, For parts of the ice of the wood, which is called "Odko" decorated with shellfish and deposited and rolled from the sea in the form of different colors or decorated with ostrich feathers, and all wooden holdings are decorated by the incorporation of color of wood with another after burning or add glue or metal Or beads or leather. Wood is less raw materials, but it needs skill and precision in manufacture because it has a soft feel. Also made Hun coffee cheese from the wood of trees (Sial) one of the Acacia and used and still Hun on a large scale for the month of coffee cheese in the eastern desert in (halaib and Shalatin) and its importance as a popular weather in the area.

\section{Traditions associated with handicrafts and heritage in the region}

\section{Eastern Desert products, coffee or cheese:}

Abu al-hassan Al-takrouni as one of the most important artists, craftsmen and heritage patrons of the region, the founder of the Halayeb Museum and the Shalatin Heritage (a special museum) describes the "cheese" as the official beverage for them, It is carried on a wooden or other piece with its cups or coffee cups by means of a standard of water, called "Shurqark". It is intended for preparing "cheese". It is easy to make by adding coffee, as well as ginger, black pepper, "Using the Hun made of wood called" Fu Netok "and is settled on the branches of trees, The "cheese" is made up of three main types, which are decorated with the name "Wdaidait" and the other, which is called "Mahayat", both of which are made of pottery. The aluminum, with some decorations, is called "Kasarunit"; for the clear of coffee is used "Tomoy" is a small wooden vase with two hands in addition to the wooden hanging. The small of them called "Mait" The big is called "Moy", this is unlike the mobile stove, which moves the woman or man to make cheese is a large dish Of the sheet, a hollow container to block the air to ignite the fire and the branches of the trees to make the coffee "cheese" after the burning of these branches inside, at many times a day, where used Basharya and Ababda drink, and there is also "ring" to cool coffee is busy black wool And red-tipped limbs, used to cool coffee after the clear.

\section{Fifth: Industries of the wool of camels and sheep: (Kilim)}

The region is characterized by its desert nature and at the same time very much famous for the raising of camels, goats, sheep, and a historical father. There was a supply of natural raw materials of wool and goat hair especially seasonally during the fur cutting of the animals which made the local community especially the ladies. This natural wealth is important, and it is a common denominator in the manufacture of (kilim) or desert carpets. The tribes of Ababdeh and Basharya knew this craft for hundreds of years and developed with the development of domestic or animal needs. If the basis of that industry was in the region, it seems that according to the observation there is the exploitation of goats' hair, which is raised in a very large number in the region,for the industry of (kilim) Or loom for use in the construction of housing tents, which called the houses of poetry, which represented one of the most important forms of houses there, especially the tents of travel, which was moving to the Bedouin families from the valley to another valley in the desert Tngola and seeking rain and water from one season to another in the desert. And has developed the degrees of exploitation of the wool produced from camels and sheep to be thought of spinning and use in the industry loom and Kilim distinctive was used as mattresses in the tent and Bedouin houses in the area and distinguish the three white cream, light 
brown and dark brown oblique of the black and formed mainly units geometrical square Or triangle and and the simpleness of the loom used, where the use of the horizontal loom said about four branches of acacia trees tight wool to form sado threads, while sitting on the head of the front of the loom and hold her hand with a stick wrapped around the wool representing the meat or welding, which makes the engineering units and Badja For the stick that represents the shuttle loom down and then the top of the (sado) and when you need to use another color using another shuttle color required. And in the recent period during the past twenty years or more slightly introduced artificial wool brought from Aswan and characterized by colors dyed artificially named yarns of silk wool and characterized by smooth texture more soft than natural wool coarse and those colored wool used for industry loom or distinctive distinctive of the region called " Hamel "is a carpet made of sheep wool and colored wool fabric and woven on the loom, which was considered one of the most important in the bride's furnishings and equipment of old, these types of carpets such as desert carpets distinctive and characterized by narrowness of the distances of (Sadu) and the accuracy of the contract and increase the number in the loom and You may distinguish using different colors And the regularity of the engineering units used, where most tend to use the shape of the triangle repetitively to form in the end a special piece of art, but this product is characterized by high price, which now amounts to 500 pounds per piece and the high price of wool used and also for the time consumed in manufacturing, Approximately 7-10 days for the manufacture of one piece length of two meters and one meter width. However, recently, with the introduction of some development projects in the region such as the World Food Organization project, looms, types and forms of (kilim) were introduced, such as loom and (Kilim Aljublan), were not seen as natural landscapes, nor were they geometric units. (Karadasa, Fuh, Assiut) and others where the women were trained on this craft and received about 30 master training on the industry of natural climbs, but he noted that there is no demand for this production for high price compared with other similar products in Egypt, 200-300 pounds while the price is in the Kurds Sho or Fooh or the old Egypt of 50-70 pounds and a maximum of 100 pounds, making competitive in this field very difficult only if developed to take a unique form outside the traditional price competition.

\section{Sixth: Other manual industries of plants and natural rocks}

\section{1-Plant industries:}

\section{The craft of the fruits of pumpkin plant:}

The creative artist in (shalatin)in both women and men has been well versed in the art of forming pumpkin fruits and in its decorative decoration of the pumpkin, using the gouache and its uses either to save the ghee or to save the toiletries of kohl and perfumes, where it needs to be processed and take the gourd plant and immersed in water to open inside and dry in the sun In pink color by massage barley leaves, and to get the blue color we attach to the surface of the dwelling after exposure to smoke by burning the branches of trees (Alsial), and then comes the next stage is the decoration of burning parts of the surface and sculpture, It is decorated with a knife where (alwada) is placed in the beads and artistic forms..

\section{2-Industries of stones}

Drilling on talc and basalt rocks: Due to the desert nature of the mountainous region and the diversity of mountains in the area and its valleys with the content of different rocks of basalt, granite, Dahab and other rocks with great geological diversity.. So it was natural to think there in the exploitation of those riches to know many of the products that were made of rocks and drilling on the rocks such as Hun and the dish or the wind or known 
as the area of the game and the milling machine is using the "marhaka" which is called "Tori" They are made of black basalt, and are drilled or picked as rock pieces, grinding the grains using another rocky hand. As some artists know there are the art of sculpture on the rocks Talc easy to form for the work of forms of animals for wild animals in the area and did not shop only was a personal coffin linked to some artists.

\section{Section II: Handicrafts in the center and north of the Red Sea:}

(Marsa Alam, Quseir, Hurghada, Gharb and Safaga)

First: Handicrafts in Marsa Alam sector

Marsa alam is a city and large center includes a number of villages, including Sheikh Shazly, Hamata, Abujaon and Qalaan and Kilo 14, and of course the city of Marsa Alam itself.

\section{Handcrafts in the city of Marsa Alam:}

\section{1-Handicrafts in Qal'an:}

Qala'an is a small village for inhabitants of the tribe of Alababdeh located directly within a lake of trees Mangrove forests and is a unique tourist area and the census of families approximately 20 families.

Men work in different jobs, including the most important profession of fishing while women practise in their spare time profession traditional handcrafted to learn from their grandmothers, which is the work of leather and beads where women produce distinctive works of natural leather blends with beads and the most important production is a special medals of leather and The beads are called (shalouk) sold to tourists coming to the area as they produce kinds of bracelets, necklaces and anklets of beads and natural leather. The village has a small camp of mats and wood. It is designed as a permanent exhibition for ladies to sell their handicrafts to tourists and visitors to the village. It also represents a small training center where training is provided, as was previously done by Tourism and Environment Association in Wadi Al - Jamal. The main handicraft products there are beads and leather bracelets (Hosseinnia,E.\& Shoja,B.,2017 ).

\section{2-Handicrafts in the city of Marsa Alam:}

The number of 15 ladies in the handcraft in the city of Marsi Alam itself, in addition to the number of 10 women in the assembly at 14 kilos south of Marsa Alam and their work mainly in beads and leather bracelets and the ladies offer their products on the nearby tourist cruise when visiting tourist trips, especially for foreigners who are sports Diving in the coasts of Marsa Alam as one of the local ladies coordinate the marketing of their works in weekly exhibitions in the nearby tourist villages or exhibitions in Cairo in cooperation with the institution manual or calls from other parties.

\section{3-Handcrafts in Hamada, Abu Ghusoon and Ras Banas:}

The villages of Hamata, Abu Ghusoun and Ras Banas are the last three villages of Marsa Alam in the south and are inhabited by a large number of hundreds of local families from the tribes of Ababdeh, where the people know mainly about hunting and grazing and sometimes some mining work in the area Some women work in their houses in handicrafts Beads and leather bracelets, some palm fronds, leather bags, in addition to some simple industries for woolen wool. There is a small handicraft center attached to one of the schools in (Hamada) village, where the ladies learned through it and the production unit of wool wool, as it is coordinated by the local ladies to coordinate the work between them when delivering the raw materials and receipt of the output. Between the sale of production points of marketing in Cairo or weekly exhibitions in the tourist villages south of Marsa Alam.

\section{4-Handcrafted by Sheikh Shazly and Hafafeet}


The village of Sheikh Al-Shazly is one of the villages belonging to the city of Mursi Alam. It is located within the Eastern Desert and from the very famous villages in Egypt, since it is named after the Sheikh Al-Arif AlAllah Abulhassan Al-Shazly where the village used to be an important point on the pilgrimage to Makkah for the people of Morocco and North Africa. Where he passed and died and buried there Sheikh Abu Hassan AlShazly and has a shrine and a large shrine and known there. The village and its small satellites such as Hafafit are inhabited by a number of tens of families. The production of ladies is currently considered semi-rare or rare due to the changing conditions of the economy and the movement and movement of most families from the disciples to the village of Sheikh Al-Shazly in the government resettlement units, Abadi previously traditional. However, the types of crafts made by some ladies were recorded during the previous years, including leather wicker industries for the work of small baskets and also leather bags of goat leathers, as well as the village of Hafeet belonging to Sheikh Shazly producing years of the finest types of wool natural wool of the flutes and camels where He was known for his distinctive geometric units associated with the Abadi and Sahrawi heritage.

\section{Second: Handicrafts in Qusair:}

Quseir is a large city with a population of about 66,000. A large part of its population belongs to the cities of Qeft and Qus and the cities and villages of Upper Egypt, where it was a trade and trade station between Upper Egypt and the cities of Hejaz through the short and well known historic ports. From there Queen Hatshepsut began her expedition to Puntland. It was also a site for gold exploration in the era of the Pharaohs. In the sixteenth century it was ruled by Sultan Selim I, whose statue is still in the center of the city. The short was of strategic strategic importance. Today it is considered a quiet tourist resort with its sandy beaches, water sports and clear water and coral reefs. 40, which is one of the largest communities of coral reefs, in addition to the region famous for the extraction of phosphate (Barrania A.,2010). And was a center for the gathering of pilgrims Muslims from Egypt, the Maghreb and Andalus to perform Hajj. Al-Qusair has Coptic and Roman ruins in Qusayr Al-Qadima, north of Kilo 8. It also has Islamic monuments, the castle and some buildings in the center of the country. The short link in the valley of the Nile road length of $180 \mathrm{~km}$ passes through the baths and reach the city of Qeft Qena. This valley has Pharaonic ruins dating back to the era of Queen Hatshepsut and the gold mine in Wadi Al-Fawkhir.

\section{The French trip for the Qusair:}

Qasr al-Qusair is an Ottoman castle used by "Muhammad Ali". A French fleet of four ships was given to carry out the order of Napoleon Bonaparte in February 1799. The Arab forces came from the Hijaz under the leadership of "Sharif Hassan" and allied with the ground forces armed, and then took the French naval fleet, which was under the command of "Colo" and then stormed a ship sank four ships and the other three to Suez.

After the naval fleet failed in the attack, Napoleon Bonaparte then led his expedition to Daisy, the leader of his expedition, to occupy and shorten his campaign. It was already occupied by (Beliar) in May 1799. He wrote to "Dizier" telling him that Al Qusayr Castle oversees the city but is far from the sea, so it is safe from the English fleet's artillery. The English fleet attacked Qusair castle in August 1799, led by Blankett, but failed after all the damage caused to the castle by the bombing of the English artillery fleet. They succeeded when they returned the ball in the Meno era after the evacuation of the French in February 1801 and then left it in June of that year. When Muhammad Ali took over Egypt in 1805. Al-Qusair played a role in the events at that time. It was entered by Muhammad Ali in June 1815 after his return from the Druze to support his son Tusun, the father of Khedive Abbas, who was fighting Sheikh Abdul Wahab and his followers. And then sent his son Ibrahim on her way in 
September 1816 to travel to the Hijaz and returned also in December 1819 and from there to Qena and from Qena to Cairo by ship. The city of Qusair in the Islamic era in general and the Mamluk period as a port of great importance was one of the main ports where the pilgrims of North Africa are going to Mecca and Medina.

\section{Architectural description of Qusair castle:}

There are four towers, the thickness of the walls from 26 to 30 is built limestone and the palace contains only a small number of rooms. It also has an entire excavated well of plaster. Its water is very heavy and salty and used for watering cattle. A hundred steps from the southwest façade outside the palace there is an old water tank that can be broken by bricks and can accommodate 45 cubic meters of water. Numerous paths descend to the bottom of the reservoir, landing from surrounding and adjacent hills so that they are naturally filled with water in the rainy season (this reservoir no longer exists). On the other side of the fort there was a mosque, several tombs or tombs, and the French had demolished them.

\section{Handicrafts in Qusair city}

Historically, it is not known in Qusair-lived industries, but only a few of the handicrafts practiced by the tribes of Al-Ababdeh, which have been inhabited since ancient times, in the suburbs. However, because of the lack of documentation of its historical stages, we have no evidence of the quality of these crafts. Red and the port of the short and the month of the people of the city on the sea and fishing craft knew about the industries of the nets of threads and if it is now a letter Almndrh as known by the ancient pastry some of its people in the art of crochet. At present, only some of the popular household handicrafts practiced by women in homes in their free time, such as crochet, oxisarates of artificial stones and copper, have been registered. A number of private associations have been registered in the short time that support women to implement and learn such activities as the Young Muslim Association in Ksayr It has a specialized women's club to organize after learning courses for women. Their products are mainly brass or crochet accessories. There is a good production of baby clothes, bed linens, cushions and some home products from crochet works. The International Labor Organization supported by the Canadian Agency to support the Association in 2013 to 2015 to carry out some exercises and raise the efficiency of the administrative team of the Association to support women beneficiaries.

\section{Third: Handicrafts in the North of the Red Sea (Hurghada, Safaga and Ras Ghareb):}

The cities of Safaga, Hurghada and Ras Gharib may be historically densely populated as they are urban and Scania (El-Gamily, I.,etal.,2001), where Safaga, for example, was based on the port and the extraction and transfer of phosphate where it began as a port and the village of Huwaitat during the late 1940s. Ras Ghareb city was founded on the oil sector recently during The last 50 years and the nature of the city naturally arose on the tourism in full during the same period and less Although there are of course a lot of people belonging to some tribes across those areas of time but did not know about them a real role in the enrichment of handicrafts there is only possible to distinguish some of the letter simple hand To his spread parish tribe Taping desert parallel to those coastal cities. The traditional crafts, as we mentioned, did not actually know that area except by mentioning the tribe of Maazah. Some of them were known as wool and embroidery with beads for the work of burqas and shilan Bedouins for their personal use and very little use of the wool to make the hair of the goats' hair. Recently, however, a large number of manual products have been registered by residents and expatriates in these cities during the last period.

\section{Safaga and Ras Ghareb:}

There are a number of private associations such as the Omar Bin Al Khattab Society in Safaga and the 
Association of Community Development Bras Garib helps in developing the skills of the women living there to teach them a new character or the development of the existing crafts. They have some skills such as crochet, brass ornaments and beads, Knitting and embroidery fabrics. An irregular number of contributions, trainees or products can be counted between 20 and 35 craftsmen in the two cities and their work is displayed at one of the marketing points of the Red Sea Governorate in Hurghada as a sole outlet for them, in addition to their participation through private associations in the annual social exhibitions such as Diyarna Produced in Cairo annually in Nasr City in the exhibition grounds.

\section{2-Hurghada city:}

Today, Hurghada is considered one of the largest cities in the Red Sea Governorate. It is therefore the capital and the largest population density, which is distributed among the vast majority of expatriates either from cities in the valley or Upper Egypt or from Cairo and the maritime side of the workers in the field of tourism and related fields in this sector (Barrania A,2010). The original became very small among some works with a letter such as fishing and others in the city of Hurghada or some of the tribes spread in the eastern desert near the city and work their people in the safari and tourist camps, such as the tribes of Rhishandih and Maazah. There are a number of private associations that support directly and indirectly the handicraft sector of the families of handicrafts such as the associations of the vocational training association in Hurghada, the women's association of the families of the Hurghada and the Islamic charitable society for the development of the society in the port in Hurghada, where their role is confined to providing some training or marketing outlets Through the exhibitions of families produced by social affairs. Some of the handicrafts, such as crochet, candle making, women's accessories, copper, lanterns, household appliances, crystal beads, and precious stones are also registered in the manufacture of curtains or bracelets, Accessories from natural shells from the Red Sea, as well as some ladies working in the detail of curtains and embroidery on the women and decoration tools. In addition, some of the artists' art has been registered, especially for expatriates, where works of art were recorded for paintings of art and craftsmanship, which is considered to be an artistic handcraft, of course, for a number of artists where they perform their work according to their creativity or on demand from some customers. Some of the marketing outlets are considered a few gardes or During the exhibitions of his time as the Marina Balgrdkp is the marketing outlet of those works and some of them display their works online and from the artists whose works were documented artist Sayed Mohammed and Nisreen Adel and Suheir Nabil.

\section{Challenges and Management of Marketing:}

The handicraft products are currently marketed in the Marsa Alam area in some of the weekly tents held in some of the tourist villages that are spread on the coast, hotels inside through exhibitions, and during exhibitions and private exhibitions in Cairo.

\section{Marketing through manual treasures company}

The target audience of the products is mainly the Red Sea tourist market in the areas of Hurghada and Marsa Alam, As these products are preferred to tourists as a souvenir explaining the heritage of the region and the local population of the Red Sea. Five million tourists visits The Red Sea annually from different nationalities of the world and spend more than 40 million nights tourism, tourists who visit ,Wadi al Gamal Nature Reserve, and Marsi Alam, are 70,000 visitors, spending between \$10-15 on gifts and craft products totaling 6,500,000 pounds annually. Unfortunately, despite the existence of dozens of tourist bazaars in Marsa Alam, it only sells products, mostly imported or a few Egyptian products such as Alabaster, but completely ignores the marketing 
of local products for women in the region.

\section{Risks and Challenges}

There are more than 350 of women in 5 communities, scattered apart, working in an unorganized in those manufactures, palm, Leather, wood, beads and pottery and they face the following problems (Teh, T.S...,2000) 1-Poor coordination and cooperation with the private sector to support the sustainable marketing of these trades and participation in ensuring the sustainability of production and marketing.

2-Weakness and scarcity of marketing of handmade products for women in tourist bazaars in the Red Sea in general.

3-The absence of an organizational form for producers and local women in the production of crafts in the southern Red Sea

4-Poor supply of raw material and lack of multiple sources and high prices and their presence only in Cairo away from the presence of producers..

5-The need for quality control and training of women on how to finish the product in a way that satisfies the product and fits different tastes according to the use of products..

6-Lack of access to local markets in Cairo and other tourist cities and the need to link those characters with the cultural and ecological identity of the region and the natural reserve (Dak,T.M.,1989)

7- Social economic transformations, in Shalaten, Currently, There is a tendency, mainly, in an economic and social transformations to change the patterns of houses or clothing and fashion, and its tendency to the city life, more than a traditional society that has roots of heritage and tradition known previously, and that not only affect the patterns or the existence of the manufacture of jewelry, but also most of the traditional handcrafts in the area..

8-The existence of a single workshop for the manufacture of traditional ornaments in the commercial market in Shalatin without the attention of the concerned parties, and the reluctance of traditional customers and they are the population and therefore, and this leads to the lack of interest of the owner of the workshop by the industry and its development. .

9-The change in the socio-economic patterns of the population of the region and the emergence of different types of beds, Sponge and cotton mattresses, and something like that, It is considered that the Anqrip wood of the past is no longer suitable for the modern house and that the reasons for its decline, and the other reason is the entry of the cheap iron element as a competitor to the Anqrip wood, and the spread of the iron industry and its development in various forms, thus the Anqrip was losing its position in the Bedouin families' homes in the region and also in Sudan, thus a new designs for beds emerged and made the use of Anqrip wood needless.

10-Pricing: In discussions with retailers indicate their willingness to tolerate locally made products, however, the prices are not competitive (compared to products from Aswan), lack of continuous supply and lack of time to visit each product as reasons for not carrying more local products (Shaalan, I. M.,2005)

11-The low density of the population and the lack of organization for Supply Chain create a gap between the producers and buyers. The only raw material naturally in the area is straw, when the animal dies, leather. Raw materials are purchased in very small quantities, and this contribute to the relatively high cost of materials in each product. Wool of camel's hair is hand weave, which takes a lot of time. These factors also contribute to non-competitive pricing. Obstacles to the development of craft projects.

12-Supply chain is not well organized, or delivered to POS.. 
13-Making a relationships with the buyer is not well, for the distance from Cairo or the tourist villages in the Red Sea, where women cut $300 \mathrm{~km}$ to sell their products in exhibitions weekly or semi-weekly.

14-The quality of the product is variable, because more than 300 ladies are working to produce what is going on in their minds without committing to a large degree in the required size. The quality varies from one hand to another, with no quality control or quality control..

15-Calculation of purchase the raw materials in small quantities. For example, when an animal is slaughtered in a wedding or daily life raw materials are purchased in very small quantities, because of the shortage of animals, monthly, on the market or among the population themselves. And even when the raw materials are come from Cairo, at high prices other than shipping and other costs. The trader does not adhere to the quality of the leather, which contributes to the relatively high cost of materials in each product. Wool of camel's hair is hand weave, which takes a lot of time. These factors also contribute to non-competitive pricing, which makes it one of the most important obstacles to the development of artisan projects well, but only a real and serious intervention improves the chain of supply and quality..

In recent years, climate changes, with the commercial development of the southern Red Sea region, threaten the continuity of rich cultural traditions in the "Alabadi Pashari".

\section{Conclusion and Sustainable development}

\section{Strategy:}

It is necessary to provide support to the Association of Red Sea Protected Areas as the largest and most important association in the South Red Sea means to revive traditional crafts and support artisans in order to support the revival of jewelery industry in the region through (Bushati,B.,2017):

1-Authentic documentation of the area's ornamental heritage during a project dedicated to documenting the heritage of the Alababdeh, Basharya and Rashaida tribes.

2-The implementation of training for a number of women and young people in the area on the basis of design and manufacture of silver and copper jewelry and gemstone vaccination can provide trainers in Cairo through cooperation with the center of Azza Fahmi heritage jewelry.

3-Technical support and financial for a number of youth Almnqota to establish a number of small workshops for heritage jewelry aimed at marketing products in the villages of tourism and the Red Sea in general.

4-Providing operational support for the current workshop by encouraging production and participation in exhibitions and directing its production in a fair manner to the tourism sector.

5-Exploitation of opportunities for proximity to the place of Sudan.

According to statistics, Sudan has about 150 million domestic animals - cattle, goats, sheep and ibex - in return for this livestock. Sudan represents an advanced place as one of the most important sources of leather in the world. In spite of the presence of many automatic tanning and municipal tanning machines, a high proportion of Sudanese leather exports to Egypt and exports to Southeast Asia. Importantly, there are imported leather points from Sudan to the Shalatin area in the commercial market and directly exploited in local industries. Especially the revival of leather sandals, bags and others.

6-revival of the manufacture of leather shoes in shallatin:

There is still a high possibility to revive and support a new generation of manufacturers of the arts of the leather industry and transform them into a kind of heritage shoes suitable for the nearby tourism markets in the Red Sea or to develop and launch from the development of traditional designs known as the area, which can be made 
from skins of cows and tanned The development of monoclonal goatskin skins is a light type popular in the case of its production and development, especially for the local market and tourism, as it is made from the skin of soft goatleather (Balzilqon), which is a herbal coating reddishness imported from Asia or some local dyes that are reliable from natural trees with (Olba) mountain Reserve..

7-Quality control and construction on the rich heritage of the region to support the crafts products from the South Red Sea region has a special value added to distinguish the heritage and historical dimension unique and distinct from the rest of the regions of Egypt in addition to the products of leather and palm art is one of the best known craft products In Egypt for what is known about the ladies Basharih and Alababdeh high in the production of these trades and the products of the Kilim is considered a kind of desert desert distinctive in Egypt, especially if the availability of production and the quality has been adjusted correctly.

8-Expanding the targeting base for marketing, tourists and visitors to the Red Sea can be reached as a tourist destination in Egypt to reach them through marketing exhibitions in the tourist villages - safaris - coordination with hotels and tourist villages - advertising and advertisement in addition to electronic marketing and supply through shops and Bazaar sale of crafts and products in the regions and tourist markets targeted in addition to the local market in Cairo to many consumers who prefer to acquire such traditional crafts as a house or for personal use as fashion and personal products (Gohar, A. \& Mathias, G.K.,2016) .

9-Launching an initiative to preserve handicrafts in the South of the Red Sea, which has funding for its clear line to preserve the traditional techniques of the crafts that are applied and produced by the population there: to promote cultural understanding through traditional products; and to provide livelihoods to the local community through the application of production techniques Traditional to the elements and linked to the mechanisms of work groups together and exercises to raise the efficiency of the ladies to produce production lines and categories of traditional products of natural heritage of bags, wallets, ornaments, and household baskets and their exclusive products that distinguish their region and Their rich heritage is important..

10-Find new uses of old products of heritage, such as (Alsheqib) can introduce new forms according to the environment can be made of pumpkin after the crunch in three directions close keep its balance when attached to the ceiling and connect with leather belts, to be a tool for decoration and placed on the pottery that holds the plant and pride or even Lighting units suspended..

11-Reviving the industry of the (Ankrib) bed in sHalatin and Halaib and the introduction of new designs especially suitable for nearby tourist villages such as small chairs or families or furniture or decorative formations in the same traditional way to manufacture traditional (Ankrib).

12-Supporting the Halayeb and Shalatin Heritage Museum and turning it into a documentation center for handicrafts and workshops for engraving on wood and drilling on talc and basalt rocks, wood engraving arts and painting arts for the natural landscapes of the region and the industry of (Ankrib).

\section{References}

- Beltagui, M. (2001) " Egypt: Tourism opportunities" . Middle East Business Intelligence, 20(4),2001,pp.7-8.

- Ngai,C.W., Ecotourism and Environmental Conservation in Small Islands in the East Coast of Peninsular Malaysia. Malaysian Journal of Environmental Management 10(2) (2009): 53-69. 
- Hikade, T. " Expeditions to the Wadi Hammamat during the New Kingdom". The Journal of Egyptian Archaeology (JEA) 92, 2006,pp.153-168.

- Wilson, A.M. "The GEF Egyptian Red Sea Coastal and Marine Resource Management Project. A decade of effort, experience and trade-offs required to achieve marine tourism and conservation goals" . In: International Tropical Marine Ecosystems Management Symposium Proceedings. Australia, 1999,pp. 239-250.

Samy, M., Sánchez Lizaso, J. L. \& Forcada, A.,. " Status of marine protected areas in Egypt" . AnimalBiodiversity and Conservation, 34.1,2011 1,pp .65-177.

Ibrahim,Z. "Tourism Development and the Environment on the Egyptian Red Sea Coast", A thesis presented to the University of Waterloo, Ontario, Canada, 2009.

Sanyal, S., Banerjee, S. and Majumder, S." India's Leather in the World Market: Exploration of Recent Trends". Trade and Development Review, 2010,pp. 22 - 58.

- Hosseinnia,E.\& Shoja,B.,." The role of handicrafts in the sustainable development of rural tourism with an emphasis on indigenous knowledge" . International Journal of Geography and Geology,

Vol. 6, No. 1, 2017 pp. 1-7.

- Barrania A., "Cost of Degradation of Coral reefs and Fisheries Caused by Tourism Development, Egypt's Red Sea A case study o f Hurghada - Safaga Area”, Institute of National Planning, Cairo, Nasr City, Egypt, 2010.

- El-Gamily, H. I., Nasr, S. and El-Raey, M. (2001). An assesment of natural and human-induced changes along Hurghada and Tas Abu Soma coastal area, Red Sea, Egypt. International Journal of Remote Sensing 22, 2999-3014.

- Teh, T.S.." Sustainable development and environmental management of Malaysian islands". Teh,

T.S. (ed.). Islands in Malaysia: Issues and challenges: 319-340. Kuala Lumpur: University of Malaya, 2000.

-Dak,T.M. "Rural Industralistation: Challenges and Responses". North Book, Delhi, 1989, p. 23-24.

Shaalan, I. M.. "Sustainable tourism development in the Red Sea of Egypt: threats and opportunities". Journal of Cleaner Production 13,2005,pp. 83-87.

- Bushati,B. " Handicrafts as an opportunity for economic development and sustainable tourism:

Shkodra case study" . Marketing and Branding Research 4, ., 2017.,pp. 64-72.

- Gohar, A. \& Mathias, G.K.," Sustainable Tourism along the Red Sea: Still Possible?". Civil Engineering and Architecture 4(2),2016,pp. 39-46.

- MAHMOUD, Samah, Abd Al-Rahman, Mohamed ISMAIL, Shaza, Gamal, ABOUSHOUK, Mohamed, FATHI, Chiresteena, Adel, SUSTAINABLE DEVELOPMENT STRATEGIES IN HERITAGE AREAS (MINIA GOVERNORATE CASE STUDY), International Journal of Eco-Cultural Tourism, Hospitality Planning and Development, Vol.3, No.2, 2020, pp.1-20.

Received: April 2021

Accepted: June 2021 